\title{
The Impact of Interactivity on Advertising Effectiveness of Corporate Websites: A Mediated Moderation Model
}

\author{
May M. Fahmy ${ }^{1} \&$ Ahmed I. Ghoneim ${ }^{2}$ \\ ${ }^{1}$ Doctoral Student, The British University in Egypt, Cairo, Egypt \\ ${ }^{2}$ Professor of Marketing, Cairo University, Egypt \\ Correspondence: May M. Fahmy, Faculty of Business Administration, Economics and Political Science, The \\ British University in Egypt, 11837, Egypt. E-mail: may.fahmy@bue.edu.eg or mayfahmy05@gmail.com
}

Received: July 24, 2016 Accepted: August 18, 2016 Online Published: September 22, 2016

doi:10.5539/ijms.v8n5p41 URL: http://dx.doi.org/10.5539/ijms.v8n5p41

\begin{abstract}
Interactivity is identified as a key component in the new media; however, the complex relationship between interactivity and advertising effectiveness measures has yielded inconclusive results. The purpose of this study is to perform a systematic investigation of the underlying mechanisms between the actual interactivity and the advertising effectiveness measures.

This paper proposes a model that empirically examines the role of the perceived interactivity in mediating the impact of actual interactivity on advertising effects; moreover, it studies the moderating role of individual differences on perceived interactivity. The empirical evidence indicates that perceived interactivity mediates the relationship between actual interactivity and purchase intention, the attitude towards the brand, and the attitude towards the website; additionally, it reveals that age plays a significant moderating role between actual and perceived interactivity. Thus, the mediated moderation model is supported. Furthermore, this paper tackles the implications of the interactivity theory building in the practice of marketing communications and interactive advertising.
\end{abstract}

Keywords: advertising effectiveness, corporate websites, interactivity, mediation model, moderators, marketing communications

\section{Introduction}

With the rapid growth of the World Wide Web, advertisers and marketers have been increasingly utilizing the new medium for advertising purposes and incorporating their corporate websites into their marketing communication mix (Goldsmith \& Lafferty, 2002; Hwang, McMillan, \& Lee, 2003; Loiacono, Watson, \& Goodhue, 2007; Stevenson, Bruner, \& Kumar, 2000; Song \& Zinkhan, 2008; van Noort, Voorveld, \& van Reijmersdal, 2012; Voorveld, Neijens, \& Smit, 2009; Wang, Wang, \& Farn, 2009; Zollet, 2014). A corporate website serves as a strategic advertising and marketing communication tool that enhances customer-relationships and fosters brand-building (McMahan, Hovland, \& McMillan, 2009) as it enables consumers to interact with the advertising message and engage with the brand (Yoo, 2009). For that reason, advertising researchers have commonly used the terms "Web-based advertising" and "interactive advertising" interchangeably (McMillan \& Hwang, 2002).

Since the uniqueness of the web over the traditional media lies in its inherent interactivity (Coyle \& Thorson, 2001; Hoffman \& Novak, 1996; Lee, Lee, Kim, \& Stout, 2004; Liu \& Shrum, 2009; McMillan \& Hwang, 2002; Voorveld et al., 2011; Wu, 2000), the effective use of websites as marketing communication and advertising vehicles entails capitalizing on its interactive nature. However, the potential of the web as an advertising medium has not been fully harnessed; the reason is that marketers and advertisers did not fully comprehend the interactivity concept and its impact on advertising effectiveness, and consequently they were unable to capitalize on the medium's attributes (Johnson, Bruner, \& Kumar, 2006; Wu, 2006).

The extant review of the interactivity literature reveals that the interactivity's effect on a number of advertising measures has yielded inconclusive results. Some research findings, on the one hand, indicated that interactivity had a positive influence on advertising effects (Chen, Griffith, \& Shen, 2005; Cho \& Leckenby, 1999; Chung \& Zhao, 2006; Hwang \& McMillan, 2002; Jee \& Lee, 2002; McMillan, 2000; Raney, Arpan, Pashupati, \& Brill, 
2003; Schlosser, 2003; Wu, 1999; Yoo \& Stout, 2001) while other researchers have found mixed or no impact whatsoever (Bezjian-Avery, Calder, \& Iacobucci, 1998; Coyle \& Thorson, 2001; Fortin \& Dholakia, 2005; Sundar, Kalyanaraman, \& Brown, 2003). A possible explanation for such inconclusive findings is that the interactivity construct has been conceptualized and operationalized differently (Bucy, 2004; Changal, 2005; Liu, 2003; Liu \& Shrum 2002). On the one hand, some researchers have investigated the influence of the feature-based interactivity on advertising effects (Bezjian-Avery et al., 1998; Boushra, 2008; Coyle \& Thorson, 2001; Fiore \& Jin, 2003). On the other hand, other researchers have examined the perception-based measures (Chen et al., 2005; Chung \& Zhao, 2006; Jee \& Lee 2002, Hwang \& McMillan 2002; Macias, 2003; Raney et al., 2003; Schlosser, 2003; Wu, 2000; Song \& Zinkhan, 2008; Yoo \& Stout, 2001). However, few empirical studies have attempted to establish a causal explanation between the interactive interfaces and the outcome measures through adopting an integrative approach that simultaneously considers both the functional aspect and the perceptual aspect of the interactivity construct (Song \& Bucy, 2008; Wu 2005). The goal of the current study is to investigate the relationship between the interface features and the advertising effectiveness measures of a website by proposing a complete model that empirically investigates the role of perceived interactivity in mediating the impact of actual interactivity on different advertising effectiveness measures (e.g., purchase intention, the attitude towards the brand, and the attitude towards the website). It will further test the influence of individual differences (e.g., age, gender, and internet self-efficacy) in moderating the relationship between actual and perceived interactivity.

\section{Conceptualizing Interactivity}

It is obvious from the interactivity literature that there have been multiple approaches to defining the concept; several attempts have been made to group such various definitions. Whereas some researchers have broadly categorized them into three or four approaches, others adopted the dichotomy approach.

Among those researches who broadly classified the interactivity definitions were McMillan \& Hwang (2002) who categorized them on the basis of process, feature, perception, on the one hand, and combined features, process and/or perception, on the other. Rafaeli viewed interactivity as a communication process construct (Rafaeli \& Sudweeks, 2006), where he defined interactivity as "an expression of the extent that in a given series of communication exchanges, any third (or later) transmission (or message) is related to the degree to which previous exchanges referred to even earlier transmissions" (1988, p. 111). By contrast, Steuer (1992) viewed interactivity from a structural perspective and defined the concept as "the extent to which users can participate in modifying the form and content of a mediated environment in real time" (p. 84) while Newhagen et al. (1995) were the first to propose the concept of perceived interactivity and defined it as "the psychological sense message senders have of their own and of the receivers' interactivity" (p. 165). Nevertheless, the extant review of empirical research on interactivity literature advocates the dichotomous approach "structural versus perceptual" (Boushra, 2008; Lee, Hong, \& Lee, 2006; Liu \& Shrum, 2002; McMillan, 2002; Pavlov \& Stewart, 2000; Song \& Bucy, 2008; Song \& Zinkhan, 2008; Stout, Villegas, \& Kim, 2001; Wu, 1999). While the structural approach regards interactivity as a medium characteristic or a feature, and it operationalizes the actual interactivity level by varying the number and kinds of the interactive features (e.g., Fortin, 1997; Raney et al., 2003; Wu, 2005; Voorveld et al., 2011), the perceptual approach tend to view interactivity as the user's subjective experience and uses an itemized scale to measure it (e.g., Song \& Bucy 2008; McMillan \& Hwang 2002; Wu, 2000).

Several scholars viewed that the relationship between the interactive elements and the perceived interactivity is far more complicated as they found that increasing the number of the website's interactive functions does not necessarily guarantee higher perceptions of interactivity (Song \& Zinkhan, 2008; Voorveld et al., 2011). Nevertheless, Stout et al. (2001) argued that although the structural and perceptual approaches of interactivity are different, they complement one other. Moreover, they asserted the importance of the structural approach as it provides the guidelines for the website's design.

In an attempt to reconcile these inconclusive findings, Wu's (2005) empirical research pioneered in integrating the two research streams of interactivity, where he proposed the role of perceived interactivity in mediating the influence of actual interactivity on the media effects. In a similar vein, Bucy \& Tao (2007) posited that perceived interactivity should be positioned as a mediator variable, and they further proposed the "mediated moderation" model that incorporates four kinds of variables: the actual interactivity as the media stimulus, the perceived interactivity as the mediator, the individual differences as the moderators, and the advertising effects as the outcome measures. In their study, Song \& Bucy (2008) empirically examined the mediating impact of perceived interactivity on the political attitudes and the websites' evaluations in addition to exploring the moderating effect of political sophistication and internet self-efficacy. Their findings supported the role of perceived interactivity in mediating the influence of actual interactivity on political evaluations and the moderating effect of internet 
self-efficacy.

Nevertheless, too little empirical research has been conducted to test a complete model that accurately explains the causal relationship between the interactive interfaces and different advertising effects. Accordingly, the researchers will empirically test a comprehensive conceptual model that will investigate the role of the perceived interactivity as a mediator of the impact of actual interactivity on different advertising effectiveness measures (e.g., purchase intention, the attitude towards the brand, and the attitude towards the website), and the influence of individual differences as moderators (e.g., age, gender, and internet self-efficacy).

\section{Advertising Effectiveness Measures}

\subsection{Attitude towards the Website}

Attitude towards the website is defined as "predisposition to respond favorably or unfavorably to web content in natural exposure situations" (Chen \& Wells, 1999, p. 28). Recent studies have indicated that the attitude towards the website is a significant measure of website advertising effectiveness (Chen \& Wells, 1999; Elliott \& Speck, 2005; Jee \& Lee, 2002; McMillan, Hwang, \& Lee, 2003; Rodgers \& Thorson, 2000; Wu, 1999). Accordingly, it is becoming increasingly crucial for web advertisers and marketers to gain positive attitudes towards their corporate websites (Wu, 1999).

Several empirical studies indicated that perceived interactivity positively influences the attitude towards the website (Ahn, Hong, \& Pedersen, 2014; Cho \& Leckenby, 1999; Hwang \& McMillan, 2002; Jee \& Lee, 2002; McMillan et al., 2003; Schlosser, 2003; Song \& Zinkhan, 2008; Wu, 2000; Yoo \& Stout, 2001). On the other hand, the findings of the studies, which investigated the relationship between actual interactivity and the attitude towards the website, were inconsistent as some studies found that actual interactivity positively influences the attitude towards the website (Boushra, 2008; Fiore \& Jin, 2003) while others indicated a mixed or negative impact (Bezjian-Avery et al., 1998; Bucy, 2004; Coyle \& Thorson, 2001; Fortin \& Dholakia, 2005; Massey \& Levy, 1999; Sundar, 2000; Sundar et al., 2003).

It is observed that the perceived interactivity positively impacts the attitude towards the website consistently, while the findings of the impact of actual interactivity on the attitude towards the website were inconsistent, accordingly $\mathrm{Wu}(2005)$ investigated the mediating role of perceived interactivity in influencing the impact of actual interactivity on attitude towards the website, and the findings supported the mediation effect. Furthermore, Song \& Bucy (2008) empirically tested a mediation model examining the mediating effect of perceived interactivity in influencing the impact of actual interactivity on political websites' evaluations, where the findings supported the mediation effects on the attitude towards the political websites, the attitude towards the content, and the attitude towards the politician.

Thus, it can be hypothesized that:

H 1: Perceived interactivity mediates the impact of actual interactivity on the attitude towards the corporate website.

\subsection{Attitude towards the Brand}

Attitude towards the brand is referred to as the overall evaluation of a particular brand (Changal, 2005, p. 17). Whereas some empirical studies indicated that the perception-based interactivity of a website positively influenced the attitude towards the brand (Changal, 2005), other empirical studies reported that the feature-based interactivity had a significant positive influence on the attitude towards the brand as well (Boushra, 2008). However, Wu's (2000) empirical research, which tended to test the impact of both actual interactivity and perceived interactivity on advertising effectiveness measures, found that only perceived interactivity positively influenced the attitude towards the brand; however, adding more interactive features did not necessarily generate favorable brand attitudes as the high level of actual interactivity may have a detrimental impact on brand attitudes if such actual interactivity level is too high for the consumers.

It is obvious that perceived interactivity consistently and positively affects the attitude towards the brand while the findings of the impact of actual interactivity on the attitude towards the brand were inconclusive. Accordingly, the researchers will adopt an integrative approach by exploring the role of perceived interactivity as a mediator of the impact of actual interactivity on brand attitudes.

Accordingly, the following hypothesis is developed:

H 2: Perceived interactivity mediates the impact of actual interactivity on the brand attitudes. 


\subsection{Purchase Intention}

Purchase intention refers to the level of likelihood of making a purchase (Changal, 2005, p. 17). Empirical evidence, regarding the relationship between interactivity and purchase intention, seems to be confusing and far from conclusive. Whereas findings of some studies indicated that perceived interactivity had a significant, direct and positive influence on purchase intention (Chniti \& Bouslama, 2015; Wu, Hu, \& Wu, 2010; Yoo \& Stout, 2001), other studies indicated that perceived interactivity did not directly influence the purchase intention (Jee \& Lee, 2002). While some studies indicated that perceived interactivity indirectly influenced purchase intention via attitude towards the website (Changal, 2005; Jee \& Lee, 2002; Karson \& Fisher, 2005), other studies indicated that the impact of perceived interactivity onto online purchase intention was transferred through trust and product evaluation (Chen et al., 2005).

Since the model proposed by Bucy \& Tao (2007) is based on the idea that perceived interactivity is a mediator of the media effects, the researchers will, accordingly, explore in this study the role of perceived interactivity as a mediator of the impact of actual interactivity on purchase intention.

Thus, the following hypothesis is developed:

H 3: Perceived interactivity mediates the impact of actual interactivity on the purchase intention.

\section{Individual Differences as Moderators}

Different researchers called for focusing on individual characteristics while examining the interactivity effects (Tremayne, 2005; Zeithaml, Parasuraman, \& Malhotra, 2002). Nevertheless, Song \& Bucy (2008) contended that the role of individual differences should not only be examined for how such differences influence the advertising effects of interactive websites but for their moderating impact on the relationship between actual interactivity and perceived interactivity. Accordingly, this study will explore the moderating influence of age and gender on the relationship between actual and perceived interactivity; in addition, it will test the moderating influence of internet self-efficacy.

4.1 Age

Prensky (2001) operationalized age as the status of consumers; either "digital natives" who were born in the digital age and are "native speakers" of the internet, or "digital immigrants" who were born pre-digital age but have adopted many aspects of the new technology at some later point in their lives. Although many media scholars accredited Presky's classical theory, several recent studies argued that the digital native-digital immigrant metaphor is misleading. In that scheme, Oblinger \& Oblinger (2005) argued that technological savviness is mainly related to technology exposure rather than being affiliated with the generational phenomena. In the same vein, Guo, Dobson, \& Petrina (2008), in their research on the effect of age on an individual's competency of Information and Communication Technology (ICT), found that there is no significant statistical relationship between age effects and (ICT) competency, where older consumers do not necessarily have lower (ICT) competencies than younger ones.

Thus, the following hypothesis is developed:

$\mathrm{H} 4 \mathrm{a}$ : The relationship between actual interactivity and perceived interactivity is moderated by age.

\subsection{Gender}

Gender refers to "the behavioral, social and psychological characteristics of males and females" (Pryzgoda \& Chrisler, 2000, p. 554). McMahan et al. (2009) explored the influence of gender differences on interactive corporate websites with respect to three kinds of interactive functions: human-computer, human-human, and human-content. They reported several gender-based differences in terms of time spent and usage on different kinds of interactive functions on the corporate websites. Although many corporations use gender segmentation in their web strategies, no research has examined the moderating role of gender on the relationship between actual interactivity and perceived interactivity.

Thus, the following hypothesis is developed:

$\mathrm{H} 4 \mathrm{~b}$ : The relationship between actual interactivity and perceived interactivity is moderated by gender.

\subsection{Internet Self-efficacy}

Eastin \& LaRose (2006) referred to (ISE) as a "belief in one's capabilities to organize and execute courses of internet actions required to produce given attainments" (p. 1), and they asserted that it is a vital construct in understanding online activities as it separates experienced internet users from novice users.

In their empirical study, Song \& Bucy (2008) explored the moderating effect of ISE on the relationship between 
actual and perceived interactivity, where findings indicated that ISE significantly moderates the relationship between actual interactivity and perceived interactivity. They contended that experienced users tend to enjoy the challenge of maneuvering highly interactive applications, the matter which results in more perceived interactivity; in contrast, novice users tend to experience anxiety due to their lack of confidence in their capability of using such new applications. Additionally, novice users tend to be confident and feel more comfortable while surfing websites with low interactivity and hence experience more perceived interactivity whereas experienced users tend to feel bored and hence this will result in less perceived interactivity.

Accordingly, it can be hypothesized that:

$\mathrm{H} 4 \mathrm{c}$ : The relationship between actual interactivity and perceived interactivity is moderated by internet self-efficacy.

\section{Methodology}

\subsection{Pilot Study}

Once the questionnaire was developed, a pilot study was conducted at the British University in Egypt on a sample of 62 participants to enhance the reliability of the questionnaire and ensure the understandability and clarity of the questions. To assess the internal consistency of scales, SPSS 23 was used, and results indicated that the cronbach's alpha values for all measurement scales were acceptable: perceived interactivity (.925), attitude towards the website (.944), attitude towards the brand (.951), and purchase intention (.888).

\subsection{Experimental Design, Sample and Stimulus Materials}

To test the model, an experiment was conducted during December 2015 at the British University in Egypt. The data were obtained from a convenience sample of 419 students and academic and administrative staff members from different faculties of the university. Among the 419 participants, $219(52.3 \%)$ were males and 200 females (47.7\%). The participants aged 18-25 years were 161 (38.4\%) while the participants aged 26-35 years were120 (28.6\%). However, those aged 36-55 years were 138 (32.9\%).

The current research employed a two website treatment (highly interactive/low interactive) within-subject experimental design to test the model. Therefore, a sample size of (838) responses was used in the analysis for the two websites. An expert panel, which was formed of digital media experts and web designers from different well established advertising and media agencies in Cairo and Dubai, chose the two stimulus websites and judged their interactivity level based on specified criteria that were developed from an updated list of the websites' interactive elements. They operationalized the actual interactivity level according to the strength or weakness of the interactive functions. The two automotive websites that were chosen were Kia Egypt website (Kia.com.eg) that represented the highly interactive website and Nissan Egypt website (Nissan.com.eg) that represented the low interactive website (see Appendix A).

\subsection{Measures}

\subsubsection{The Actual Interactivity of Websites}

For statistical analysis purposes, the website with high-interactivity was coded 1 and the low-interactivity website was coded 0 .

\subsubsection{Perceived Interactivity}

The scale of perceived interactivity was adopted from Wu (2000); this scale includes nine items (see Appendix B). Each item was measured with a seven-point Likert-type scale ranging from strongly disagree (1) to strongly agree (7).

\subsubsection{Purchase Intention}

The scale of measurement for purchase intention was adopted from Changal (2005); it is composed of three items (see Appendix C). Each item was measured with a seven-point Likert-type scale ranging from strongly disagree (1) to strongly agree (7).

\subsubsection{Attitude towards the Website}

Attitude towards the website was measured using the scale developed by Chen and Wells (1999); this scale includes six items (see Appendix D). Such items were measured using a seven-point Likert-type scale ranging from strongly disagree (1) to strongly agree (7).

\subsubsection{Attitude towards the Brand}

Attitude towards the brand was measured using a seven point semantic differential scale developed by Raman 
(1996); this scale includes four items (see Appendix E).

\subsubsection{Internet Self-efficacy}

The scale of internet self-efficacy was adapted from Song \& Bucy's (2008) scale. This scale, as shown in Appendix F, includes four items, where each item was measured with a seven-point Likert-type scale ranging from strongly disagree (1) to strongly agree (7).

\subsubsection{Age}

Age was categorized as follows: (1) 18-25 years, (2) 26-35 years, (3) $36-55$ years.

\subsubsection{Gender}

Gender was assigned a dichotomous variable: $(1=$ male, $2=$ female $)$.

\subsection{Procedure}

The experiment was conducted in different computer laboratories of the university that are equipped with internet access. Participants were asked to browse the two automotive websites to find more information about car specifications. After browsing each website participants were requested to fill in an online questionnaire that measured their online experience. Participants were also asked to assume that they have the financial resources to make any purchase. The survey instrument was created in English language on SurveyMonkey website (www.surveymonkey.com).

\subsection{Statistical Procedure}

\subsubsection{Mediation Test Using Structural Equation Model}

The mediation model entails a causal relationship, where the actual interactivity of the website impacts perceived interactivity, which consequently influences the attitude towards the website, purchase intention, and attitude towards the brand. To test the interactivity's mediation model, a structural equation modeling using AMOS 23 was conducted.

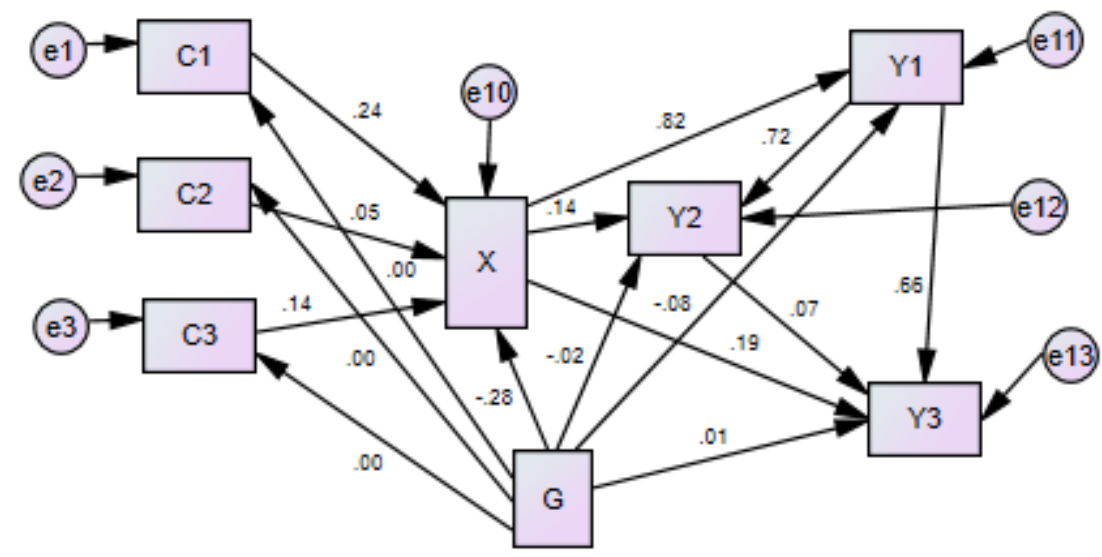

Figure 1. Path diagram of full saturated model

Note. $\mathrm{X}=$ perceived interactivity, $\mathrm{G}=$ actual interactivity, $\mathrm{C} 1=$ internet self-efficacy, $\mathrm{C} 2=$ age, $\mathrm{C} 3=$ gender, $\mathrm{Y} 1=$ attitude towards the website, $\mathrm{Y} 2=$ attitude towards the brand, $\mathrm{Y} 3=$ purchase intention, $\mathrm{e}=$ error.

According to the suggested cut-off values (Hair, Black, Babin, \& Anderson, 2010), the goodness of fit indices of the full saturated model demonstrated no good fit to the sample data: chi-square statistics $=38.384, d f=12$, chi-square $/ d f=3.199, \mathrm{p}=0.000, \mathrm{GFI}=0.989$, RMSEA $=0.051$, CFI $=0.993$, AGFI $=0.967$, TLI $=0.983$. The regression weights showed that some path coefficients were significant at $\mathrm{P}$-value $<0.10$ significant level while other path coefficients of the model were statistically insignificant. Thus, the fit indices as shown in figure 1 were not adequate and required improvement to better fit the sample data. After several trials using all the above criteria and the modifications indices, the initial model was improved through deleting those standardized factor loadings of items less than 0.1 . Accordingly, eight paths and one latent variable were dropped as follows: actual interactivity to internet self-efficacy, age, gender, attitude towards the website, attitude towards the brand, and purchase intention; age to perceived interactivity; and attitude towards the brand to purchase intention in addition 
to the latent variable age.

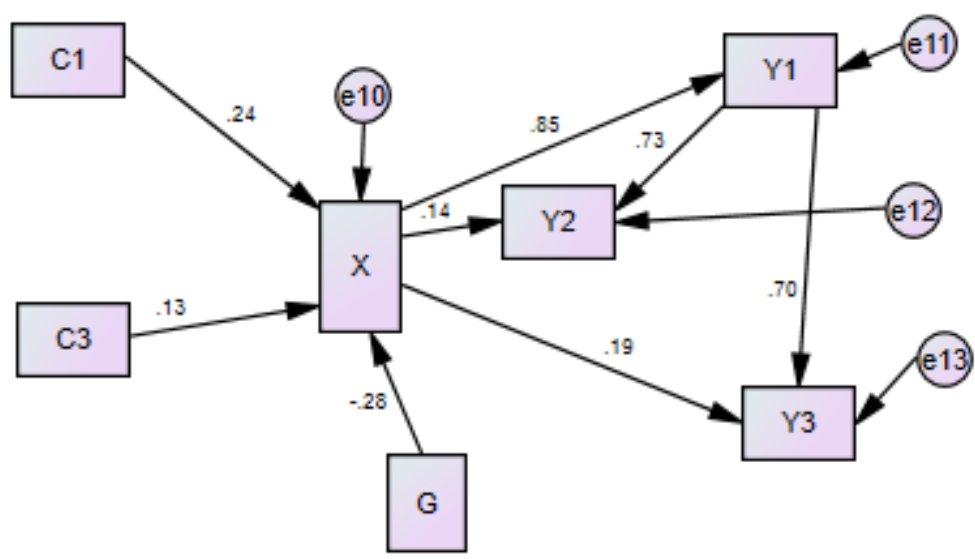

Figure 2. Path diagram of final model

Note. $\mathrm{X}=$ perceived interactivity, $\mathrm{G}=$ actual interactivity, $\mathrm{C} 1=$ internet self-efficacy, $\mathrm{C} 3=$ gender, $\mathrm{Y} 1=$ attitude towards the website, $\mathrm{Y} 2=$ attitude towards the brand, $\mathrm{Y} 3=$ purchase intention, $\mathrm{e}=$ error.

As shown in figure 2, the final overall structural model demonstrated a good fit for the sample data: chi-square statistics $=38.726, d f=13$, chi-square $/ d f=2.979, \mathrm{p}=0.000, \mathrm{GFI}=0.987$, RMSEA $=0.049, \mathrm{CFI}=0.993$, AGFI $=0.972, \mathrm{TLI}=0.988$. The regression weights show that all the path coefficients are significant at $\mathrm{P}$-value $<0.000$.

The final model shows that actual interactivity was found to significantly affect perceived interactivity (P-Value $<0.05)$. Nevertheless, perceived interactivity significantly affected the attitude towards the website, purchase intention, and attitude towards the brand (P-Value $<0.001$, and loading greater than 0.1 ), while actual interactivity had no significant impact on either the attitude towards the website, purchase intention, or attitude towards the brand; accordingly, the mediation model was supported.

According to such findings, perceived interactivity was found to be a significant mediator of the relationship between actual interactivity and the attitude towards the website, attitude towards the brand and purchase intention, supporting $\mathrm{H} 1, \mathrm{H} 2$, and $\mathrm{H} 3$.

Table 1. Standardized total effects by website (Kia's website-unconstrained)

\begin{tabular}{lllllll}
\hline & $\mathrm{C} 2$ & $\mathrm{C} 3$ & $\mathrm{C} 1$ & $\mathrm{X}$ & $\mathrm{Y} 1$ & $\mathrm{Y} 2$ \\
\hline $\mathrm{X}$ & -.127 & .113 & .266 & .000 & .000 & .000 \\
$\mathrm{Y} 1$ & -.099 & .088 & .207 & .781 & .000 & .000 \\
$\mathrm{Y} 2$ & -.081 & .072 & .169 & .637 & .657 & .000 \\
$\mathrm{Y} 3$ & -.088 & .078 & .184 & .693 & .665 & .112 \\
\hline
\end{tabular}

Note. $\mathrm{X}=$ perceived interactivity, $\mathrm{C} 1=$ internet self-efficacy, $\mathrm{C} 2=$ age, $\mathrm{C} 3=$ gender, $\mathrm{Y} 1=$ attitude towards the website, $\mathrm{Y} 2=$ attitude towards the brand, $\mathrm{Y} 3=$ purchase intention.

By taking Kia's website as an example, table 1 shows a strong positive impact of perceived interactivity on the attitude towards the website (.781), purchase intention (.693), and attitude towards the brand (.637). However, age inversely affects perceived interactivity, the attitude towards the website, purchase intention, and attitude towards the brand; the values were (-.127), (-.099), (-.088), (-.081) respectively.

\subsubsection{Moderating Tests: Age, Gender, and Internet Self-efficacy}

To test the moderating role of age-group on the relationship between actual and perceived interactivity, a 2 (low and high actual interactivity) $\times$ a 3 (18-25, 26-35, and 36-55 age-groups), a two-way analysis of variance (ANOVA) test with interaction was performed as shown in table 2.

Results indicated a significant impact of actual interactivity on perceived interactivity, $F(1,832)=76.697$, $\mathrm{p}=0.000,(\mathrm{p}<0.01)$. The highly interactive website $(\mathrm{Kia})$ reported $(\mathrm{M}=4.922, \mathrm{~S} . \mathrm{E}=0.050)$ while the low interactive website (Nissan) reported $(\mathrm{M}=4.236, \mathrm{~S} . \mathrm{E}=0.063)$. Results revealed that there was a significant impact 
of age-group on perceived interactivity, $F(2,832)=3.115, p=0.045,(p<0.05)$, where respondents of age-group 26-35 reported $(M=4.709, S . E=0.080)$ while respondents aged 18-25 reported $(M=4.469, S . E=0.066)$. However, there was no significant difference between the age group (36-55) and the other two age groups.

First and foremost, the interaction between actual interactivity and age-group on perceived interactivity was significant at $F(2,832)=16.190$ and $p=0.000,(p<0.01)$ as shown in figure 3 . The youngest age-group 18-25 years experienced the highest perceived interactivity of the highly interactive website "Kia" (M=5.095), followed by the older age group 25-35 years $(M=4.881)$, then followed by the oldest age-group 36-55 years $(\mathrm{M}=4.756)$.

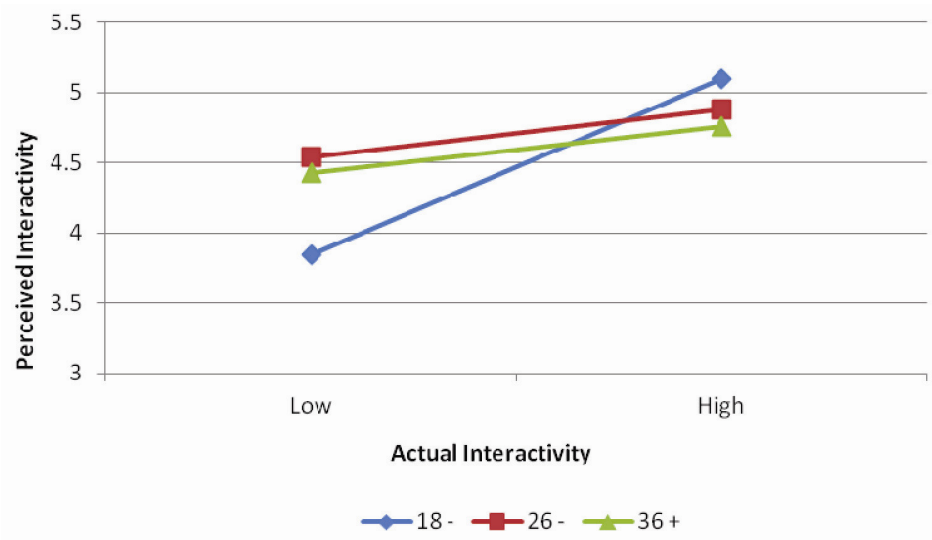

Figure 3. Interaction for actual interactivity and age-group on perceived interactivity

As shown in table 3, the youngest age-group 18-25 years experienced the lowest perceived interactivity of the low interactive website "Nissan" $(M=3.845)$, followed by 36-55 age group $(M=4.429)$, then followed by 26-35 age group $(\mathrm{M}=4.539)$. Accordingly, age moderates the impact of actual interactivity on perceived interactivity. Thus, H4a was supported.

Table 2. Two-way ANOVA with interaction between the 2 websites according to age

\begin{tabular}{llllll}
\hline Source of variation & SS & d.f. & MS & F-ratio & Significance \\
\hline Actual Interactivity & 98.521 & 1 & 98.521 & 76.697 & $0.000(\mathrm{P}<0.01)$ \\
Age & 8.004 & 2 & 4.002 & 3.115 & $0.045(\mathrm{P}<0.05)$ \\
Actual Interactivity*Age & 41.603 & 2 & 20.802 & 16.190 & $0.000(\mathrm{P}<0.01)$ \\
Model & 148.128 & 5 & 29.626 & 23.058 & $0.000(\mathrm{P}<0.01)$ \\
Residual & 1068.996 & 832 & 1.285 & & \\
Total & 1217.124 & 837 & & & \\
\hline
\end{tabular}

Note. $\mathrm{SS}=$ standard deviation, d.f. $=$ degree of freedom, $\mathrm{MS}=$ mean square.

Table 3. Descriptive statistics of perceived interactivity according to actual interactivity * age

\begin{tabular}{|c|c|c|}
\hline Actual Interactivity & 0 & 1 \\
\hline \multicolumn{3}{|l|}{ Age-group } \\
\hline $18-25$ & 3.845 & 5.095 \\
\hline $26-35$ & 4.539 & 4.881 \\
\hline $36-55$ & 4.429 & 4.756 \\
\hline
\end{tabular}

Note. $0=$ low interactive website, $1=$ highly interactive website.

To examine the moderating effect of gender, a 2 (low and high actual interactivity) $\times 2$ (males and females), a two-way ANOVA test with interaction was performed. As shown in table 4, results indicated no significant interaction between actual interactivity and gender, $\mathrm{F}(1,834)=0.963, \mathrm{p}=0.327(\mathrm{p}>0.05)$; thus, H4b was not supported. 
Table 4. Two-way ANOVA with interaction between the 2 websites according to gender

\begin{tabular}{llllll}
\hline Source of variation & SS & d.f. & MS & F-ratio & Significance \\
\hline Actual Interactivity & 98.521 & 1 & 98.521 & 75.683 & $0.000(\mathrm{P}<0.01)$ \\
Gender & 21.258 & 1 & 21.258 & 16.175 & $0.000(\mathrm{P}<0.01)$ \\
Actual Interactivity*Gender & 0.265 & 1 & 0.963 & 0.963 & $0.327(\mathrm{P}>0.05)$ \\
Model & 121.043 & 3 & 40.348 & 30.700 & $0.000(\mathrm{P}<0.01)$ \\
Residual & 1096.080 & 834 & 1.314 & & \\
Total & 1217.124 & 837 & & & \\
\hline
\end{tabular}

Note. $\mathrm{SS}=$ standard deviation, d.f. $=$ degree of freedom, $\mathrm{MS}=$ mean square.

Additionally, to examine the moderating effect of ISE on the relationship between actual and perceived interactivity a 2 (low and high actual interactivity) $\times 2$ (low and high internet self-efficacy), a two-way ANOVA test with interaction was performed.

A median-split analysis was used to obtain the ISE factor and divide respondents into high and low groups. As shown in table 5, results reported no significant interaction between actual interactivity and ISE at $\mathrm{F}(1,834)$ $=0.136, \mathrm{p}=0.712(\mathrm{p}>0.05)$; accordingly, $\mathrm{H} 4 \mathrm{c}$ was not supported.

Table 5. Two-way ANOVA with interaction between the 2 websites according to ISE

\begin{tabular}{llllll}
\hline Source of variations & SS & d.f. & MS & F-ratio & Significance \\
\hline Actual Interactivity & 98.521 & 1 & 98.521 & 75.683 & $0.000(\mathrm{P}<0.01)$ \\
Internet Self-efficacy & 32.768 & 1 & 32.768 & 25.172 & $0.000(\mathrm{P}<0.01)$ \\
Actual Interactivity*Internet Self-efficacy & 0.177 & 1 & 0.177 & 0.136 & $0.712(\mathrm{P}>0.05)$ \\
Model & 131.466 & 3 & 43.822 & 33.664 & $0.000(\mathrm{P}<0.01)$ \\
Residual & 1085.658 & 834 & 1.302 & & \\
Total & 1217.124 & 837 & & & \\
\hline
\end{tabular}

Note. $\mathrm{SS}=$ standard deviation, d.f.=degree of freedom, $\mathrm{MS}=$ mean square.

\section{Discussion}

This study empirically tested the mediated moderation model proposed by Bucy \& Tao (2007); furthermore, it advanced the study of interactivity by exploring the role of perceived interactivity in mediating the impact of actual interactivity on two key advertising effectiveness measures: purchase intention and brand attitude and by scrutinizing the moderating role of two key individual differences (age and gender).

The result of the mediating influence of perceived interactivity on the attitude towards the website of this study was in line with the previous studies (Song \& Bucy, 2008; Wu, 2005), where the role of perceived interactivity as a mediator of the impact of actual interactivity on the attitude toward the website was supported. Moreover, the mediating effects of perceived interactivity on purchase intention and the attitude towards the brand were supported as well. Thus, the whole mediated model was supported.

The current study attempted to further investigate the explanatory power of individual differences in generating different levels of users' perceived interactivity for the same interactive interface by exploring the moderating role of age and gender in addition to examining the moderating effect of internet self-efficacy. The results indicated that the age-group moderated the relationship between actual interactivity and perceived interactivity while gender and internet self-efficacy did not. One of the key findings of this study is that the youngest age-group 18-25 years was the most efficient age group in internalizing the different levels of interactivity. The users of this age-group experienced a higher feeling of perceived interactivity for the highly interactive website (Kia) than the users of the other two age-groups, and they experienced the lowest sense of perceived interactivity for the low interactive website (Nissan). Although few researches have investigated the moderating effect of internet self-efficacy, and they argued that it significantly influences perceived interactivity (Song \& Bucy, 2008). However, the current study found no moderating effect for internet self-efficacy. Possible explanations for this might be due to the drastic improvement in the internet skills in the past few years, or it might be linked to cultural differences between participants in the two studies and to how individuals tend to evaluate their own internet capabilities in these two different cultural contexts. According to the findings of the current study, the mediated moderation model was supported. The model posits that individual differences (e.g., age) moderates the influence of actual interactivity on perceived interactivity, and that perceived interactivity mediates the influence of actual interactivity on key advertising effectiveness measures: purchase intention, attitude towards 
the brand, and attitude towards the website. Thus, interactivity has a positive impact on the advertising effectiveness, while taking into account the role of perceived interactivity as a mediator and of the role of the individual differences as moderators.

\section{Contribution of Research}

\subsection{Theoretical Contribution}

This research contributes to the theory building for interactivity by proposing and testing a comprehensive mediated moderation model that integrates both the functional and perceptual aspects of interactivity and their effects on different marketing communication and advertising measures, while taking into account the impact of different key variables (mediator and moderators) that regulate the relationship between them. It expands the body of the theoretical knowledge by revealing the mediating influence of perceived interactivity on purchase intention and attitude towards the brand as well. Furthermore, it proves that individual differences, as age, influence the customer's perception of the corporate website and accordingly moderates the impact of actual interactivity on perceived interactivity, thus contributing to the further explanation of the reason why the same media stimulus may have differential effects on different users.

In the light of the ever-changing interactive technologies, this study, nevertheless, provides guidelines on the updated interactive features that could be integrated into corporate websites and hence facilitate the operationalization of the actual interactivity nowadays.

\subsection{Practical Contribution}

The findings of this research offer several valuable insights for the interactive marketing communication practice. It encourages corporate managers to invest in upgrading their interactive technology. It provides useful insights for advertisers and marketing communication managers on how to effectively develop an interactive strategy that targets different audience of different age groups, where the findings suggest designing a corporate website with high levels of actual interactivity when targeting the youngest age-group (18-25 years). It would enable web-designers to build interactive websites by helping them determine the optimal level of actual interactivity that would generate the desirable degree of perceived interactivity.

\section{Limitations}

The restricting effect that the limitations of this study, namely using a convenience sample and a one-product category as a stimulus material may seem to possess has turned out to positively benefit the research. On the one hand, although using a convenience sample could limit the generalizability of the results to a wider population, the sample comprised different age groups, different educational levels and different specializations. On the other hand, concerning the one-product category to which the stimulus was limited, experts reached a consensus that the nature of the selected product category enables the inclusion of numerous interactive elements (e.g., videos, customization feature, social network features, a $360^{\circ}$ interactive view of the interior/exterior of the vehicle, online forums, etc.).

\section{Acknowledgments}

The authors would like to acknowledge the support of Zenithoptimedia Agency (Dubai \& Cairo), Fortune Promoseven Advertising Agency (part of McCann Worldgroup), and Tarek Nour Advertising Agency for their valuable input in choosing the stimulus websites, developing the updated criteria against which the websites were compared, and judging their actual interactivity.

\section{References}

Ahn, T., Hong, M., \& Pedersen, P. (2014). Effects of perceived interactivity and web organization on user attitudes. European Sport Management Quarterly, 14(2), 111-128. http://dx.doi.org/10.1080/16184742.2014.880496

Bezjian-Avery, A., Calder, B., \& Iacobucci, D. (1998). New media interactive advertising vs. traditional advertising. Journal of Advertising Research, 38(4), 23-32.

Boushra, M. (2008). The influence of web site feature-based interactivity on users' attitudes and online behaviors (Unpublished doctoral dissertation). The Pennsylvania State University.

Bucy, E. (2004). Interactivity in society: Locating an elusive concept. The Information Society, 20(5), 373-383. http://dx.doi.org/10.1080/01972240490508063

Bucy, E., \& Tao, C. (2007). The mediated moderation model of interactivity. Media Psychology, 9(3), 647-672. http://dx.doi.org/10.1080/15213260701283269

Changal, K. (2005). Effect of perceived interactivity of online stores on purchase intention (Unpublished master's 
thesis). Washington State University, United States.

Chen, Q., \& Wells, W. (1999). Attitude toward the site. Journal of Advertising Research, 39(5), 27-37.

Chen, Q., Griffith, D., \& Shen, F. (2005). The effects of interactivity on cross-channel communication $\begin{array}{llll}\text { effectiveness. Journal of Interactive } & \text { Advertising, } & \text { 5(2), }\end{array}$ http://dx.doi.org/10.1080/15252019.2005.10722098

Chniti, N., \& Bouslama, N. (2015). Effects of perceived interactivity on commercial web sites' experiential value. International Journal of Innovation and Scientific Research, 16(12), 514-525. Retrieved from http://www.ijisr.issr-journals.org/

Cho, C., \& Leckenby, J. (1999). Interactivity as a measure of advertising effectiveness: antecedents and consequences of interactivity in web advertising. Proceedings of the 1999 Conference of the American Academy of Advertising Gainesville, FL (pp. 162-179). University of Texas, Austin, United States.

Chung, H., \& Zhao, X. (2006). Effects of perceived interactivity on web site preference and memory: Role of personal motivation. Journal of Computer-Mediated Communication, 10(1). http://dx.doi.org/10.1111/j.1083-6101.2004.tb00232.x

Coyle, J., \& Thorson, E. (2001). The effects of progressive levels of interactivity and vividness in web Marketing sites. Journal of Advertising, 30(3), 65-77. http://dx.doi.org/10.1080/00913367.2001.10673646

Eastin, M., \& LaRose, R. (2006). Internet self-efficacy and the psychology of the digital divide. Journal of Computer-Mediated Communication, 6(1). http://dx.doi.org/10.1111/j.1083-6101.2000.tb00110.x

Elliott, M., \& Speck, P. (2005). Factors that affect attitude toward a retail web site. Journal of Marketing Theory and Practice, 13(1), 40-51. http://dx.doi.org/10.1080/10696679.2005.11658537

Fiore, A., \& Jin, H. (2003). Influence of image interactivity on approach responses towards an online retailer. Internet Research, 13(1), 38-48. http://dx.doi.org/10.1108/10662240310458369

Fortin, D. (1997). The impact of interactivity on advertising effectiveness in the new media (Unpublished doctoral dissertation). University of Rhode Island.

Fortin, D., \& Dholakia, R. (2005). Interactivity and vividness effects on social presence and involvement with a web-based advertisement. Journal of Business Research, 58(3), 387-396. http://dx.doi.org/10.1016/s0148-2963(03)00106-1

Goldsmith, R., \& Lafferty, B. (2002). Consumer response to web sites and their influence on advertising effectiveness. Internet Research, 12(4), 318-328. http://dx.doi.org/10.1108/10662240210438407

Guo, R., Dobson, T., \& Petrina, S. (2008). Digital natives, digital immigrants: An analysis of age and ICT competency in teacher education. Journal of Educational Computing Research, 38(3), 235-254. http://dx.doi.org/10.2190/ec.38.3.a

Hair, J., Black, W., Babin, B., \& Anderson, R. (2010). Multivariate Data Analysis (7th ed.). Upper Saddle River, NJ: Prentice Hall.

Hoffman, D., \& Novak, T. (1996). Marketing in hypermedia computer-mediated environments: Conceptual foundations. Journal of Marketing, 60(3), 50. http://dx.doi.org/10.2307/1251841

Hwang, J., \& McMillan, S. (2002). The role of interactivity and involvement in attitude toward the web site. Proceedings of the 2002 Conference of the American Academy of Advertising (pp. 10-17).

Hwang, J., McMillan, S., \& Lee, G. (2003). Corporate web sites as advertising. Journal of Interactive Advertising, 3(2), 10-23. http://dx.doi.org/10.1080/15252019.2003.10722070

Jee, J., \& Lee, W. (2002). Antecedents and consequences of perceived interactivity. Journal of Interactive Advertising, 3(1), 34-45. http://dx.doi.org/10.1080/15252019.2002.10722066

Johnson, G., Bruner II, G., \& Kumar, A. (2006). Interactivity and its facets revisited: Theory and empirical test. Journal of Advertising, 35(4), 35-52. http://dx.doi.org/10.2753/joa0091-3367350403

Karson, E., \& Fisher, R. (2005). Predicting intentions to return to the web site: Extending the dual mediation hypothesis. Journal of Interactive Marketing, 19(3), 2-14. http://dx.doi.org/10.1002/dir.20040

Lee, B., Hong, J., \& Lee, W. (2006). How attitude toward the web site influences consumer brand choice and confidence while shopping online. Journal of Computer-Mediated Communication, 9(2). http://dx.doi.org/10.1111/j.1083-6101.2004.tb00282.x 
Lee, S., Lee, W., Kim, H., \& Stout, P. (2004). A comparison of objective characteristics and user perception of web sites. Journal of Interactive Advertising, 4(2), 61-75. http://dx.doi.org/10.1080/15252019.2004.10722088

Liu, Y. (2003). Developing a scale to measure the interactivity of websites. Journal of Advertising Research, 43(2), 207-216. http://dx.doi.org/10.2501/jar-43-2-207-216

Liu, Y., \& Shrum, L. (2002). What is interactivity and is it always such a good thing? Implications of definition, person, and situation for the influence of interactivity on advertising effectiveness. Journal of Advertising, 31(4), 53-64. http://dx.doi.org/10.1080/00913367.2002.10673685

Liu, Y., \& Shrum, L. (2009). A dual-process model of interactivity effects. Journal of Advertising, 38(2), 53-68. http://dx.doi.org/10.2753/joa0091-3367380204

Loiacono, E., Watson, R., \& Goodhue, D. (2007). WebQual: An instrument for consumer evaluation of web sites. International Journal of Electronic Commerce, 11(3), 51-87. http://dx.doi.org/10.2753/jec1086-4415110302

Macias, W. (2003). A preliminary structural equation model of comprehension and persuasion of interactive advertising brand web sites. Journal of Interactive Advertising, 3(2), 36-48. http://dx.doi.org/10.1080/15252019.2003.10722072

Massey, B., \& Levy, M. (1999). Interactivity, online journalism, and English-language web newspapers in Asia. Journalism \& Mass Communication Quarterly, 76(1), 138-151. http://dx.doi.org/10.1177/107769909907600110

McMahan, C., Hovland, R., \& McMillan, S. (2009). Online Marketing communications: Exploring online consumer behavior by examining gender differences and interactivity within internet advertising. Journal of Interactive Advertising, 10(1), 61-76. http://dx.doi.org/10.1080/15252019.2009.10722163

McMillan, S. (2000). Interactivity is in the eye of the beholder: Function, perception, involvement, and attitude toward the web site. In M. A. Shaver (Ed.), Proceedings of the 2000 Conference of the American Academy of Advertising (pp. 71-78). East Lansing, MI: Michigan State University.

McMillan, S. (2002). A four-part model of cyber-interactivity: Some cyber-places are more interactive than others. New Media \& Society, 4(2), 271-291. http://dx.doi.org/10.1177/14614440222226370

McMillan, S., \& Hwang, J. (2002). Measures of perceived interactivity: An exploration of the role of direction of communication, user control, and time in shaping perceptions of interactivity. Journal of Advertising, 31(3), 29-42. http://dx.doi.org/10.1080/00913367.2002.10673674

McMillan, S., Hwang, J., \& Lee, G. (2003). Effects of structural and perceptual factors on attitudes toward the website. Journal of Advertising Research, 43(4), 400-409. http://dx.doi.org/10.2501/jar-43-4-400-409

Newhagen, J., Cordes, J., \& Levy, M. (1995). Nightly@nbc.com: Audience scope and the perception of interactivity in viewer mail on the internet. Journal of Communication, 45(3), 164-175. http://dx.doi.org/10.1111/j.1460-2466.1995.tb00748.x

Oblinger, D., \& Oblinger, J. (2005). Educating the Net generation (1st ed.). Educause. Retrieved from http://www.educause.edu/ir/library/pdf/pub7101.pdf

Pavlou, P., \& Stewart, D. (2000). Measuring the effects and effectiveness of interactive advertising. Journal of Interactive Advertising, 1(1), 61-77. http://dx.doi.org/10.1080/15252019.2000.10722044

Prensky, M. (2001). Digital natives, digital immigrants Part 1. On The Horizon, 9(5), 1-6. http://dx.doi.org/10.1108/10748120110424816

Pryzgoda, J., \& Chrisler, J. (2000). Definitions of gender and sex: The subtleties of meaning. Sex Roles, 43(7/8), 553-569. http://dx.doi.org/10.1023/A:1007123617636

Rafaeli, S. (1988). Interactivity: From new media to communication. In R. Hawkins, J. Wiemann, \& S. Pingree (Eds.), Advancing Communication Science: Merging Mass and Interpersonal Processes (1st ed., pp. 110-134). Newbury Park, CA: Sage: Beverly Hills.

Rafaeli, S., \& Sudweeks, F. (2006). Networked interactivity. Journal of Computer-Mediated Communication, 2(4), 0-0. http://dx.doi.org/10.1111/j.1083-6101.1997.tb00201.x

Raman, N. (1996). Determinants of desired exposure to interactive advertising (Unpublished doctoral dissertation). The University of Texas at Austin.

Raney, A., Arpan, L., Pashupati, K., \& Brill, D. (2003). At the movies, on the web: An investigation of the effects of entertaining and interactive web content on site and brand evaluations. Journal of Interactive Marketing, 
17(4), 38-53. http://dx.doi.org/10.1002/dir.10064

Rodgers, S., \& Thorson, E. (2000). The interactive advertising model: How users perceived and process online ads. Journal of Interactive Advertising, 1(1), 42-61. http://dx.doi.org/10.1080/15252019.2000.10722043

Schlosser, A. (2003). Experiencing products in the virtual world: The role of goal and imagery in influencing attitudes versus purchase intentions. Journal of Consumer Research, 30(2), 184-198. http://dx.doi.org/10.1086/376807

Song, I., \& Bucy, E. (2008). Interactivity and political attitude formation. Journal of Information Technology \& Politics, 4(2), 29-61. http://dx.doi.org/10.1080/19331680802076082

Song, J., \& Zinkhan, G. (2008). Determinants of perceived web site interactivity. Journal of Marketing, 72(2), 99-113. http://dx.doi.org/10.1509/jmkg.72.2.99

Steuer, J. (1992). Defining virtual reality: Dimensions determining telepresence. Journal of Communication, 42(4), 73-93. http://dx.doi.org/10.1111/j.1460-2466.1992.tb00812.x

Stevenson, J., Bruner, G., \& Kumar, A. (2000). Webpage background and viewer attitudes. Journal of Advertising Research, 40(1-2), 29-34. http://dx.doi.org/10.2501/jar-40-1-2-29-34

Stout, P., Villegas, J., \& Kim, H. (2001). Enhancing learning through use of interactive tools on health-related websites. Health Education Research, 16(6), 721-733. http://dx.doi.org/10.1093/her/16.6.721

Sundar, S. (2000). Multimedia effects on processing and perception of online news: A study of picture, audio, and video downloads. Journalism \& Mass Communication Quarterly, 77(3), 480-499. http://dx.doi.org/10.1177/107769900007700302

Sundar, S., Kalyanaraman, S., \& Brown, J. (2003). Explicating web site interactivity: Impression formation effects in political campaign sites. Communication Research, 30(1), 30-59. http://dx.doi.org/10.1177/0093650202239025

Tremayne, M. (2005). Lessons learned from experiments with interactivity on the web. Journal of Interactive Advertising, 5(2). http://dx.doi.org/10.1080/15252019.2005.10722100

Van Noort, G., Voorveld, H., \& Van Reijmersdal, E. (2012). Interactivity in brand web sites: Cognitive, affective, and behavioral responses explained by consumers' online flow experience. Journal of Interactive Marketing, 26(4), 223-234. http://dx.doi.org/10.1016/j.intmar.2011.11.002

Voorveld, H., Neijens, P., \& Smit, E. (2009). Consumers' responses to brand websites: an interdisciplinary review. Internet Research, 19(5), 535-565. http://dx.doi.org/10.1108/10662240910998887

Voorveld, H., Neijens, P., \& Smit, E. (2011). The relation between actual and perceived interactivity. Journal of Advertising, 40(2), 77-92. http://dx.doi.org/10.2753/joa0091-3367400206

Wang, K., Wang, E., \& Farn, C. (2009). Influence of web advertising strategies, consumer goal-directedness, and consumer involvement on web advertising effectiveness. International Journal of Electronic Commerce, 13(4), 67-96. http://dx.doi.org/10.2753/jec1086-4415130404

Wu, G. (1999). Perceived interactivity and attitude toward website. In M. S. Roberts (Ed.), Proceedings of the 1999 Conference of the American Academy of Advertising (pp. 254-262). Gainesville, FL: University of Florida.

Wu, G. (2000). The Role of perceived interactivity in interactive ad processing (Unpublished doctoral dissertation). The University of Texas at Austin.

Wu, G. (2005). The mediating role of perceived interactivity in the effect of actual interactivity on attitude toward

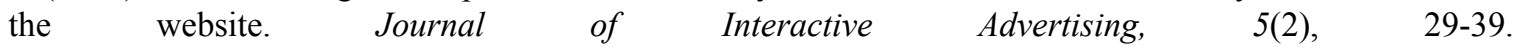
http://dx.doi.org/10.1080/15252019.2005.10722099

$\mathrm{Wu}, \mathrm{G}$. (2006). Conceptualizing and measuring the perceived interactivity of websites. Journal of Current Issues \& Research in Advertising, 28(1), 87-104. http://dx.doi.org/10.1080/10641734.2006.10505193

$\mathrm{Wu}, \mathrm{G} ., \mathrm{Hu}, \mathrm{X} ., \mathrm{W} \mathrm{Wu}, \mathrm{Y}$. (2010). Effects of perceived interactivity, perceived web assurance and disposition to trust on initial online trust. Journal of Computer-Mediated Communication, 16(1), 1-26. http://dx.doi.org/10.1111/j.1083-6101.2010.01528.x

Yoo, C. (2009). Effects beyond click-through: Incidental exposure to web advertising. Journal of Marketing Communications, 15(4), 227-246. http://dx.doi.org/10.1080/13527260802176419 
Yoo, C., \& Stout, P. (2001). Factors affecting users' interactivity with the web site and the consequences of users' interactivity. Proceedings of the 2001 Conference of the American Academy of Advertising (pp. 53-60). Villanova, PA: Villanova University.

Zeithaml, V., Parasuraman, A., \& Malhotra, A. (2002). Service quality delivery through web sites: A critical review of extant knowledge. Journal of the Academy of Marketing Science, 30(4), 362-375. http://dx.doi.org/10.1177/009207002236911

Zollet, R. (2014). Interactivity of corporate websites: An integrative review of the literature. IEEE Trans. Profess. Commun., 57(1), 2-16. http://dx.doi.org/10.1109/tpc.2014.2305795

\section{Appendix A. Comparison Table of the 2 Corporate Websites Based on Their Actual Interactivity}

\begin{tabular}{|c|c|c|}
\hline & Nissan Egypt & Kia Egypt \\
\hline \multicolumn{3}{|l|}{ Navigation } \\
\hline Site Map & 1 & 2 \\
\hline Is the Top Navigation structured and elaborated with sub menus & 0 & 2 \\
\hline Is it easy to navigate to a target content/page & 1 & 2 \\
\hline \multicolumn{3}{|l|}{ Cross Browser Functionality } \\
\hline Is the Website compatible with all major browsers i.e., Safari, Chrome \& Firefox & 1 & 2 \\
\hline \multicolumn{3}{|l|}{ Device Compatibility } \\
\hline Mobile \& Desktop (responsive website) & 0 & 2 \\
\hline Existence of Mobile Application & 0 & 2 \\
\hline \multicolumn{3}{|l|}{ Website Appearance } \\
\hline Clarity of text & 1 & 2 \\
\hline Text Heavy & 1 & 1 \\
\hline Visual Heavy & 1 & 2 \\
\hline Well-managed Design & 1 & 2 \\
\hline \multicolumn{3}{|l|}{ Content Availability } \\
\hline Search Bar & 0 & 0 \\
\hline Product Details & 2 & 2 \\
\hline Interactive Content (e.g. videos) & 1 & 2 \\
\hline Are contents editable by the user (web 2.0) & 0 & 0 \\
\hline Interactive View of the product i.e. 3-D view, zoom in/out, etc ... & 0 & 2 \\
\hline \multicolumn{3}{|l|}{ Call to Action } \\
\hline Lead Form & 0 & 0 \\
\hline Direct Interaction - contact number, email address or live chat & 1 & 1 \\
\hline Response Time for a request (in progress) & 0 & 2 \\
\hline \multicolumn{3}{|l|}{ Social Connect } \\
\hline Facebook, Twitter, LinkedIn, Pinterest, g+ & 1 & 2 \\
\hline YouTube Channel & 1 & 2 \\
\hline \multicolumn{3}{|l|}{ Local Listing } \\
\hline Address of Showrooms \& Service Centers & 1 & 2 \\
\hline Total Score & 14 & 28 \\
\hline
\end{tabular}

Note. $0=$ not available, $1=$ basic, $2=$ maximum in meeting the criteria.

\section{Appendix B. Perceived Interactivity Scale}

\begin{tabular}{ll}
\hline Factor & Items \\
\hline Perceived Control & 1. I was in control of my navigation through this website. \\
& 2. I was in control over the content of this website that I wanted to see. \\
3. I was in control over the pace of my visit to this website.
\end{tabular}

Note. Adopted from Wu (2000). 


\section{Appendix C. Purchase Intention Scale}

Items

1. The likelihood that I would shop on this website is high.

2. I would be willing to buy a product on this website.

3. I would like to recommend this website to my friend.

Note. Adopted from Changal (2005).

\section{Appendix D. Attitude towards the Website Scale}

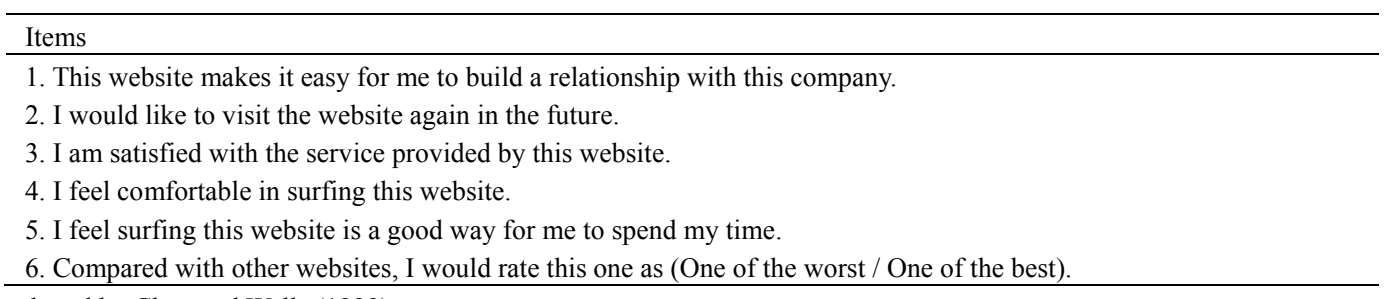

Note. Developed by Chen and Wells (1999).

\section{Appendix E. Attitude towards the Brand Scale}

\begin{tabular}{l}
\hline Items \\
\hline Unfavorable 1234567 Favorable \\
Dislike 1234567 Like \\
A poor Quality brand 1234567 A high quality brand \\
Unappealing 1234567 Appealing \\
\hline
\end{tabular}

Note. Adopted from Raman (1996).

\section{Appendix F. Internet Self-efficacy Scale}

Items
1. I have a lot of self confidence when using the Internet/Web.
2. I feel that I'm as good as using the Internet/Web as most other people.
3. I consider myself well qualified to take part in online activities.
4. There are many ways to influence the content and character of the Internet/Web.

Note. Adapted from Song and Bucy (2008).

\section{Copyrights}

Copyright for this article is retained by the author, with first publication rights granted to the journal.

This is an open-access article distributed under the terms and conditions of the Creative Commons Attribution license (http://creativecommons.org/licenses/by/4.0/). 